\title{
Parties for Rent? Ambition, Ideology, and Party Switching in Brazil's Chamber of Deputies
}

\author{
Scott W. Desposato* \\ Department of Political Science \\ University of Arizona \\ Tucson AZ 85721 \\ swd@u.arizona.edu
}

\begin{abstract}
Party switching by legislators has been common in many countries, including the Philippines, Italy, Nepal, Ecuador, Russia, and Japan. While frequently dismissed as simply an indicator of a weak parties, switching provides a unique window on party systems. To the extent that we understand affiliation decisions, we gain insight on the way politicians use parties to advance their careers. In this paper I offer a model of party membership patterns, where decisions to switch party or to stay put are a function of the strategic interaction of legislators and endogenous party leaders.

I test the model on the case of Brazil, where switching is common. Results suggest that Brazilian legislators use parties to maximize pork, ideological consistency, and short-term electoral success, but which of these matters most depends on constituents - i.e., legislators use parties for different purposes in different electoral environments. The approach developed here could easily be applied to study legislative behavior in other political systems.
\end{abstract}

*For their comments and suggestions, I thank Ben Bishin, Brian Crisp, Greg Johnson, David Karol, Kris Kanthak, Laura Langer, Mark Hugo Lopez, Bill Mishler, Pam Singh, Ben Smith, and Mike Thies. For excellent research assistance, I thank Moema Bonelli. 


\section{Introduction}

Madison's admonishments about the dangers of faction aside, most scholars agree that parties are quite useful for the consolidation of effective and stable democracies. Political parties organize and aggregate social interests, consolidating lines of political conflict. They regularize democratic practices, and serve as mechanisms for compromise and representation. They decrease voters' information costs (especially in an environment with many candidates) and increase governments' accountability to voters.(Cox and McCubbins, 1993; Snyder Jr. and Ting, 2001; Aldrich, 1995). Scholars have even linked party systems' characteristics to countries' economic policies.(Mainwaring, 1999; Haggard and Kaufman, 1995; Johnson and Crisp, 2003)

While parties are useful for democracies, scholars argue that parties are equally useful for ambitious politicians. During elections, parties can provide campaign workers, financial support, and well-developed policy brand names. Parties can control access to desired career opportunities, and may enhance politicians' access to government pork.

Many countries, however, have party systems that apparently provide few such benefits to polity or politicians. Parties in these systems are weakly institutionalized, very fluid, and highly volatile. They typically lack distinct ideological platforms, have low discipline within legislative delegations, and suffer volatile levels of popular support. Given the important role parties play in shaping and stabilizing democratic political arenas, a key task for comparative political scholars has been explaining the nature of party systems and suggesting mechanisms to strengthen them. ${ }^{1}$

One oft-overlooked window on party systems is switching by politicians. While switching is relatively rare in most countries, it has been common in many countries, including South Africa, Japan, Bolivia, Ecuador, Nepal, Russia, the Philippines, France, Italy, and Brazil. Such behavior is usually dismissed as an indicator that "parties don't matter", but I argue that party switching warrants study for at least three reasons.

First, frequent switching makes it clear that parties do matter - otherwise politicians would not bother to switch. Second, and more importantly, switching provides a unique window on politicians' underlying preferences, including their incentives for belonging to 
political parties. An examination of patterns of party affiliations can reveal the roles parties play in meeting politicians' varied career challenges. This increases our understanding of inchoate party systems; it also aids in the design of party-strengthening institutions. Finally, switching poses a normative problem for representation in mass democracies. Parties are the primary mechanism linking voters and politicians in modern mass democracies. Meaningful and stable party labels enable voters to make identify optimal candidates and cast appropriate ballots. Party switching, however, violates the basic electoral pact and effectively makes party labels meaningless.

In this paper I offer a model of party affiliations, where membership patterns are a function of the strategic interaction of individual legislators and political parties. Legislators try to maximize utility, a function of the payoffs of membership in each party and their own attributes, less a transaction cost associated with switching. Parties invite, reject, or expell members to maximize the utility of a majority of their current members, a function of exogenous and endogenous resource endowments.

I apply my model to the case of Brazil. I show that political institutions and mass attitudes combine to create a very fluid market for parties and legislators, consistent with observed frequent switching. More than a third of deputies switch party during their terms, some as many as seven times. Brazilian parties' lack of cohesion and stability has earned them the label of "party for rent" and inspired Sartori (1993) to call Brazil, "the anti-party system."

The empirical results are consistent with theoretical predictions, and offer several insights about the Brazilian party system. The strongest motives for party affiliation are access to distributive resources, electoral opportunities, and compatible policy positions. But which is most important varies with voters' characteristics. In less-developed electoral environments, legislators are most concerned with parties' access to government largess. In more developed regions, legislators are less concerned with pork access and relatively more concerned with ideological credibility.

The paper proceeds in several steps. Section 2 presents a formal model of party switching and discusses its empirical implications. Section 3 tests the model on the case of Brazil. Section 4 discusses broader implications and generalization to other cases. 


\section{A Model of Party Switching}

Most previous work on party switching is empirical, examining explanations for and the impact of switching in countries where it is frequent. In nearly all cases, however, a common theme is the intersection of institutions, ambition, and constituency characteristics. For example, Mershon and Heller (2004a) link frequent switching in Italy to electoral rules, discipline, and party size, arguing that the interaction of discipline and policy disagreements prompts MP's to leave their parties. Mejia (1999) explores switching in Ecuador, explaining variance as a function of district magnitude, party size, and party ideology. Several scholars have explored the dynamics of the LDP's breakup in Japan. Cox and Rosenbluth (1995) argue that the end of the Cold War and an economic downturn led to factional splits and defections, especially by electorally marginal parliamentarians. Reed and Scheiner (2002) focus on the behavior of individual legislators, finding that defection from the ruling party is predicted by policy and foward-looking institutional preferences of legislators, in addition to immediate electoral concerns.

Two important theoretical contributions are the work of Aldrich and Bianco (1992) and Mershon and Heller (2004b). Both model legislators' decisions as interdependent - one legislator's decision depends on the anticipated strategic behavior of other legislators. Mershon and Heller (2004b) take an important step forward by examining the interaction of legislators and party leaders. They model party leaders as setting levels of discipline and legislators responding with switch or stay put strategies. They predict cascades - where one switch prompts a series of party membership changes. Their model is entirely spatial in payoffs and utilities and does not fully endogenize the role of party leaders.

Most relevant for this project is the work of Aldrich and Bianco (1992), who model candidates' decisions to join one of two parties prior to an election. They examine the strategic behavior of challengers and incumbents seeking re-election. Their model includes primary and general elections and the value of party labels. They find that competition for a party's nomination can prompt party switches, and in the context of declining party strength, will lead to cascades of party defections. Their model is built for the US' singlemember district, two-party system, and predicts switching in the context of a decaying 
party or realignment (specifically the collapse of the Whigs in the 1850's or the realignment of conservative Southerners since the 1970's).

In this section I present an alternative model of party membership. My approach is very similar to that of Aldrich and Bianco (1992), but generalizes their approach to other political systems, allowing for different kinds of payoffs to membership, different kinds of party structure, and endogenous party leadership decisions. In the following I present a typology of party systems, consider the logic of a market for party membership, then formalize the model and derive empirical implications.

A Typology of Party Systems I propose conceptualizing legislative party systems according to the nature of the benefits that party membership provides and the extent to which parties control access to such benefits, summarized in Table 1. The benefits of party membership may be classified either as private or as club goods. Private goods are both rival and exclusive, meaning that their consumption reduces the amount of that good available to others, and others can be excluded from enjoying the same good. Examples in legislatures often include pork, committee assignments, and nominations for elected office. Club goods fall between private and public goods. They are nonexclusive only for club members, all of whom automatically enjoy equal access. For example, one club good is the electoral value of a party label. All members automatically enjoy (or suffer) a party's reputation or performance in government. ${ }^{2}$

The second dimension of my typology is the extent to which political parties control access to the benefits of membership. In the case of private goods benefits, a party might make all decisions about distribution. For example, in most closed-list systems, ballot positions for upcoming elections may be considered a private good controlled by the party leaders. In other systems, private goods need not be controlled by parties. For example, nominations in the United States are still effectively private goods but are controlled by voters in primary elections, not party leaders. With club goods, parties cannot restrict members' enjoyment of benefits. Again, all members enjoy a party's brand name or reputation. Parties do control enjoyment of club goods, however, when they can restrict membership to a subset of legislators, repelling or expelling unwelcome members. The framework proposed by Aldrich 
and Bianco (1992) is a special case of type II, where politicians compete in a single-member district for a private good (a nomination or seat) without any interferance from party leaders.

Legislators switch party to maximize their expected career utility, a function of the resources they receive from their party of choice, less a switching transaction cost. Transaction costs can take many forms, codified in law or imposed by informal institutions. For example, Nepal, Ecuador, and Japan have passed laws whereby party-switchers are expelled from office, losing their mandates. ${ }^{3}$ Alternatively, transaction costs can be imposed by voters. Where the electorate or party militants are very partisan or otherwise use parties as information cues, switchers will usually have little credibility and difficulty attracting votes or campaign support.

Parties will offer resources and invite switchers when the benefits of welcoming a new member exceed the costs of resources offered. The value of a new member will vary greatly across systems, depending on political institutions and voters' characteristics, but at least two benefits to accepting new members are obvious. First, in all legislatures, size matters. On average, larger parties have more political influence, more cabinet positions, better committee assignments, and more pork. The relationship between size and resources may occasionally be linear, when resources are distributed proportionately. In such a case, each additional member brings equal value in party resources. But in winner-take-all systems and multiparty coalition governments, the value of an additional member depends on whether he/she changes the balance of power. Second, switchers may bring with them electoral support for their new party. Especially popular politicians, often celebrities, may significantly increase a party's vote share. Such a benefit, however, depends on the electoral context. Voting must be personalistic enough that voters will continue to vote for a switcher and the electoral system must pool votes, so that other party members will directly benefit from the influx of popular support.

Formalizing the Model When formalized, this logic makes predictions about the patterns and frequency of switching across systems. I illustrate with a simple model, following Aldrich and Bianco (1992). Let a legislature have two parties, $A$ and $B$, and two legislators 1 and 2. Legislator 1 starts in party $A$; legislator 2 starts in party $B$. Each legislator has 
an additional exogenous characteristic, $g_{i}$, that is their contribution or value-added to a club good of the party they join. For example, a very popular politicians might bring votes to a new party. $g_{i}$ need not be positive; a scandal-ridden legislator might have a negative value-added in a party.

Parties have exogenous resource endowments $\theta_{j}$ and endogenous resource endowments $f\left(G_{j}\right)$. $\theta_{j}$ may be a private or club good. $f\left(G_{j}\right)$ is a club good enjoyed by all members. Its value is determined by $f$, a strictly increasing function and $G_{j}$, the sum of the $g_{i}$ of all members of party $j: G_{j}=\sum g_{i j}$. When possible, parties exercise control over access to resources by restricting membership. Specifically, members of each party cast simultaneous votes to determine which legislators will be allowed to join or stay, and which will be refused admission. Party members - themselves legislators in my model - cast these votes to maximize their own expected payoffs.

Legislators switch party or stay put to maximize their expected utility, a function of the resources they will receive in their party of choice, less any transaction costs. Legislator $i$ 's utility associated with membership in party $j$ is:

$$
u_{i j}=\alpha_{i j} \theta_{j}+f\left(G_{j}\right)-T_{i} I_{j \neq h o m e}
$$

where $\theta_{j}$ is party $j$ 's resources, $\alpha_{i j}$ is legislator $i$ 's share of party $j$ 's resources, $f\left(G_{j}\right)$ is the value of the public good contribution of all party members to party $j$, and $T_{i}$ is a transaction cost paid if legislator $i$ switched party. The precise form that payoffs and $f\left(G_{j}\right)$ takes will vary with the specific goods that contribute to parties' value for and contributions to legislators, and legislators' value-added for parties.

Two points deserve mention. First, the model is not explicitly spatial, but can easily capture spatial or non-spatial payoffs. For example, letting $\tau_{j}$ be party $j$ 's ideal point, and $\gamma_{i}$ be legislator $i$ 's ideal point, write $\alpha_{i j}=-\left|\tau_{j}-\gamma_{i}\right|$. Similarly, one could set $f\left(G_{j}\right)=$ $n_{j}-\sum\left|\theta_{j}-g_{i}\right|$ where $n_{j}$ is the number of members in party $j$. In this case, legislators' payoffs are a function of the value of a party label $\theta_{j}$ times their distance from the party. Similarly, parties weigh the added benefit of an additional member $\left(n_{j}+1\right)$ versus the cost of increased ideological dispersion $-\left|\theta_{j}-g_{i}\right|$ when deciding whether to admit legislator $i$ or not. Second, in this version of the game, parties can only invite/retain or reject/expell 
members. If payoffs $\theta_{j}$ were non-discrete private goods, the model could be relaxed so that parties set $\alpha_{i j}$ - legislator $i$ 's promised share of party $j$ 's goods. Effectively parties could make continuous offers to current and prospective members.

The game is played as follows:

1. If parties have control over membership, they simultaneously decide whether to accept or reject each legislator $i$ via majority vote of current members.

2. Legislators make membership decisions - switching or staying put - and receive payoffs.

3. The game ends.

For the simple case with one legislator per party, the payoffs of membership for each legislator are summarized in Table 2. Legislators start in the upper-right hand cell: $(A, B)$. Note that where parties have control over access, a decision to reject a member eliminates that legislator's options. For example, if Party A, controlled by legislator 1, decides to exclude legislator 2 , the first column from Table 2 is eliminated, and the game is reduced to legislator 1 choosing between Party A and Party B.

Virtually any standard game can emerge from combinations of parameter values, functional forms, and levels of party control. When legislators can freely join any party, i.e., parties cannot restrict access, the most common results include:

- Nobody Move: When $T$ is big, both legislators stay put in their current party.

- All Aboard!: when the payoff differential $\left|\theta_{A}-\theta_{B}\right|$ is big enough, both legislators join the resource-rich party.

- Battle of the Sexes: When $f\left(g_{1}+g_{2}\right)$ is big enough and all $g_{i}$ positive, both legislators want to be in the same party, but each prefers that other switch and pay the transaction $\operatorname{cost} T_{i}$. Similarly, when $\theta$ is a private good or both $g_{i}$ are less than zero, i.e., each legislator has a negative value-added, legislators may play BOTS but prefer to be in opposite parties. 
- Fashion: One legislator prefers to share a party with the other, but the other prefers to be alone. This result emerges when one legislator has a sufficiently large positive $g_{i}$ and the other a sufficiently negative one, and leads to mixed-strategy equilibrium.

- Get out! Without party control, a legislator with a negative $g_{i}$, starting in a resourcepoor party could join the other party and force the other legislator to abandon ship. The first legislator could then keep all the resources of the wealthy party for herself.

In the case where parties can reject new members, the range of parameters that lead to switching equilibria is much smaller, and some are eliminated entirely. For example, for BOTS2, Fashion, and Get Out!, the resource-rich party will simply reject unwanted new members. ${ }^{4}$

Figures 1-4 show predicted equilibria for different types of goods $\theta$, different degrees of party control, and different values of $T$ and $g_{i}$, with $\alpha=1$ for club goods and $\alpha=\frac{1}{n_{j}}$ for private goods, where $n_{j}$ is the number of members of party $j$. Each of the four figures corresponds to one of the ideal system types of Table 1. Within each figure, the four plots show equilibria for different values of $T$ and $G$, as labeled. Combinations of $\theta_{A}$ and $\theta_{B}$ which lead to All Aboard! are black, those $\theta$ that lead to Nobody Move are white, and $\theta$ that lead to mixed or other switching equilibria are grey. Thus systems with switching have large shaded regions; systems where switching is rare have large blank regions. Code to produce similar graphs and calculate payoffs for different types of goods and values of all parameters is available on my website.

Comparing the figures generates predictions about the conditions under which we will observe party switching, and the direction of such switching. The most important of these predictions include:

- Increasing transaction costs eliminates switching.

Within all of the figures, moving from $T=0$ to $T=2$ significantly reduces switching. For example, in Figure 1, compare plot $I$ with $I I$. In $I$, there is always unconstrained switching. In the plot immediately below that one, the range of $\theta$ that lead to switching falls to $64 \%$. A similar vertical comparison of plots in almost all figures yields different 
percentage changes, but identical results - the range of $\theta$ that leads to switching falls in every case.

- Increasing resource differentials $\left|\theta_{A}-\theta_{B}\right|$ leads to All Aboard! Both legislators join the well-endowed party, with important qualifications.

Without party control, increasing party resource differentials leads to switching as legislators play All Aboard or other strategies, for both kinds of goods. The range of $\theta$ that lead to switching is much larger for club goods than for private goods, because club goods are nonrival.

With party control and club goods, the impact of resource differentials is unchanged. An important exception arises with party control and private goods. In this scenario, all switching is less likely as party resource differentials increase. When parties control valuable private goods, they will not share them unless a new member brings a $g_{i}$ that exceeds the cost of sharing. In the simple illustration, parties only accept switcher $i$ when $g_{i}>\frac{\theta_{j}}{2}$.

- Negative $g_{i}$ decrease switching; positive $g_{i}$ increase switching

Where parties control access and $g_{i}$ is positive, party $j$ will accept new member $i$, except when $\theta_{j}$ is a private good and $\frac{\theta_{j}}{2}>g_{i}$. But where $g_{i}$ is negative, parties will always exclude that member if they can.

Where parties cannot restrict membership, a negative $g_{i}$ reduces the range of $A l l$ Aboard! and increases the ranges of mixed-strategy and other equilibria discussed above.

Adding more legislators and more parties increases the complexity of the model considerably, but the basic implications remain unchanged.

\section{An Application to Brazil}

In this section, I apply the model to the case of Brazil. I begin with an overview of switching in that country. I then consider the institutional and societal incentives that create a very 
fluid market for party membership. Key features of this market are relatively low transaction costs, payoffs that are either club goods or uncontrolled private goods, large resource differentials, and positive value-added for most legislators. Combined, these parameters create and structure many opportunities for defection from parties.

\section{Switching in Brazil}

Brazil has some of the highest rates of party switching in the world - exceeding $1 / 3$ of deputies during the average legislative session. In some countries, switching appears to be a short-term transitional phenomenon associated with democratization and the "gelling" of a new party system or a short-term political realignment. This is not the case in Brazil - switching is apparently chronic and enduring. Table 3 shows switching rates in the last several legislatures. During the 49th legislature (1991-1994), there were 262 incidents of switching, for an average switching rate of .52 per legislator-term. That figures slips slightly to .41 in the second period, rises to .51 in the third.$^{5}$ Further, while switching was quelled by Brazil's military regime, it was apparently common during the Second Republic (19461964) and there is even evidence of frequent switching during the First Republic (18891930).(Graham, 1990)

Switching has not escaped the attention of students of Brazilian politics, though previous work has focused primarily on the impact of switching - treating party membership decisions as an explanatory variable. For example, Nicolau (1996) examines the impact of switching on party size, finding that switching changes relative party and coalition strength in the Chamber of Deputies. He speculates that switching is prompted by ideological conflict, personal disagreements, or electoral opportunities, but suggests that separating these empirically would be impossible. Mainwaring and Liñán (1997) examine patterns of switching and party discipline in the Constituent Assembly, finding that switchers tend to have lower than average agreement scores in their party of origin, and substantially higher agreement scores in their destination parties. Schmitt (1999) examines the impact of switching on re-election rates for legislators, reporting slight negative effects on electoral success among switchers that seek re-election, but without controlling for strategic candidacies. And Melo (2000) provides a descriptive look at party-switching from 1985-1999, finding that switching 
is more common among conservative than leftist parties, though switches from both sides can traverse the political spectrum. He concludes by challenging the notion that Brazil's parties can be considered cohesive or institutionalized.

My goal is to explain party affiliation patterns and shed light on the Brazilian party system. Applying my theoretical framework to the case of Brazil requires considering the nature of payoffs, transaction costs, and legislators' value-added in the Brazilian context. As I discuss below, for many Brazilian legislators, transaction costs are very low, value-added is usually but not always positive, and key payoffs of membership are not pure private goods. Consequently, most parties are willing to accept new members, and legislators are prone to switch when resource differentials are large. There is variance on these general themes across legislators and parties.

\section{Transaction Costs}

Transaction costs are manageably low for many Brazilian legislators. The legal environment is very accomodating: there are no legal prohibitions on party-switching, except immediately prior to elections for those seeking re-election. ${ }^{6}$ Until recently, all incumbents were guaranteed renomination in the next election under the candidato nato or "birthright" rule. ${ }^{7}$ Further, personalistic voting means that switchers can take their voters with them. Partisanship in Brazil is relatively low (Samuels, 2004), and most switchers I interviewed expected no or little repercussions in terms of electoral support. Many seemed to think that voters simply didn't care about party membership. In one interview, the legislator's receptionist wasn't even aware that he had switched parties!

Some legislators, however, face significant transaction costs for switching. A few Brazilian parties have aggressively cultivated partisan followings, building grassroots organizations, promoting cohesive policy platforms, and encouraging partisan, not personal votes in campaigns. Most notable of these is the Workers' Party, or PT, but some smaller parties (including the Green Party) also have more ideological popular followings.(Keck, 1995; Mainwaring, 1999; Ames, 2001; Samuels, 2004) And even catch-all parties may have a few committed partisan supporters. Legislators with such constituencies can't take their voters with them when changing party - and should be much more likely to stay put. 


\section{Benefits of Party Membership}

Brazilian parties can facilitate access to pork, provide ideological or policy benefits, and can directly facilitate electoral success. One of the unique features of the Brazilian system is that the primary benefits of party membership are either club goods or uncontrolled private goods, facilitating a fluid party system. I'll discuss the nature of benefits and parties' role in their distribution in the following paragraphs.

Pork A major benefit of party membership is priveleged access to state resources. In the case of Brazil, scholars have widely acknowledged the importance of state resource distribution for deputies' careers.(Abrúcio, 1998; Ames, 2001, 1995a,b; Leal, 1977; Mainwaring, 1997, 1999; Pereira and Mueller, 2004; Samuels, 2003). Government resources can be channeled into pork projects that provide lucrative construction contracts and needed infrastructure. Cushy jobs in the bureaucracy reward campaign workers and maintain politicians' support networks for the next election. Resources might also be used in less legal ways - for direct campaign activities or even vote-buying.

Public resource distribution is controlled by the executive branch, not political parties. For legislators, access to public funds and resources is maximized by joining the governing coalition and voting for the executive's proposals. Brazilian Presidents typically use state resource distribution to build multiparty supermajority coalitions. Supermajorities are required because legislators, even in the governing parties, are hesitant to support controversial economic reforms that impose significant costs on their constituents. ${ }^{8}$ Finally, there are stark differentials in access to resources across parties. Legislators in opposition parties are unlikely to receive any government projects for their constituents.

Two empirical implications follow. First, government parties should retain and attract members, given large resource differentials and open market for votes and pork. Second, since pork is a rival good, governing parties' attractiveness may decline as the coalition reaches a saturation point.

A similar logic applies to subnational coalitions. Brazil's decentralized federalism grants subnational political actors - especially state governors - control over resources that national legislators covet.(Mainwaring, 1999; Abrúcio, 1998; Samuels, 2003) State governors' influence 
should only be enhanced by progressive ambition in Brazil. Many national deputies aspire to state and local elected and appointed positions. Governors directly control key state appointments and can facilitate election to subnational office by providing campaign resources, endorsements, and selective pork distribution. Consequently, governismo - a tendency to join the governing coalition to enhance resource access - ought to extend to subnational governments, making state governors' parties more relatively more attractive than state opposition parties.

Electoral Payoffs Brazilian parties play a limited, but important role in elections. In many political systems, parties provide many electoral resources: campaign workers, financing, consulting services, and meaningful labels to cue voters. But most Brazilian parties play little or no active role in legislative campaigns - parties do not provide candidates with volunteers, campaign finance, or consulting services - candidates must generate these resources on their own. Party labels are generally not used by most voters as information cues; most citizens cast votes based on candidates' reputations, not based on their partisanship.(Mainwaring, 1999, page 122) But party membership still can have an important effect on electoral outcomes. A quirk in the Brazilian electoral system, open-list proportional representation (OLPR), makes election easier in some parties than in others and affects legislators' affiliation incentives. ${ }^{9}$ The OLPR vote-pooling mechanisms allow the minimum number of votes required for election to vary across party and state. For example, a single, very popular candidate could draw millions of votes - earning several seats for her party. Because of vote pooling, her extra votes could make election easier for other candidates within her party.

Consequently, legislators have incentives to switch party to take advantage of easier electoral quotas. Parties where election is easier should retain members; parties where election requires more votes should lose members. This should vary with legislators' own electoral strength. Marginal legislators should be concerned about their party's electoral quotient. Politicians that barely passed the electoral threshold should seek another party where they could be elected with a safer margin. At the other extreme, strong vote-getters don't need to pay any attention to quotients; their election would be assured in any party. In interviews, legislators have described these calculations: comparing their own expected vote share with 
the electoral quotient in each party, and switching to enhance re-election prospects.

Electoral quotas are effectively uncontrolled club goods. Enjoying a party's quota just requires joining the party. Ballots are unordered, so legislators do not compete for list position. And every party has a surplus of nominations: parties can nominate more candidates than there are seats in every district, and rarely find enough willing candidates. Consequently, legislators should adopt membership strategies to take advantage of party quota differentials.

Ideological Payoffs A third component of party affiliation payoffs is ideological. Membership in a party of like-minded legislators has several payoffs. Political parties can play an important role in helping like-minded legislators advance a policy agenda. In addition, a political party acts as a "brand name", providing information to voters about a legislator's policy positions.(Aldrich, 1995; Snyder Jr. and Ting, 2001) Further, membership in an ideologically incompatible party can have significant costs. Legislators will be less able to advance their preferred agenda, potentially angering voters and frustrating legislator's own policy goals. Parties might also punish their less-compatible members - giving them fewer advancement opportunities, refusing to support their proposals, or even preventing them from speaking on the floor. As a result, legislators should prefer membership in ideological proximate parties, and avoid those far from their own ideal points. Ideological compatibility is clearly a club good. All legislators enjoy or suffer their compatibility with their copartisans. Differentials in ideological agreement should prompt legislators' switching to, or staying in, the most compatible party.

Pork or Policy? Legislators may have to balance competing desires for state resources and ideological compatibility. In such situations, their behavior should reflect constituents' demands. Legislators from less-developed regions should prioritize access to state resources to deliver the public infrastructure their constituents need. Legislators from more-developed regions should be more responsive to ideological concerns, as basic infrastructural needs have been satisfied. This logic implies interacting pork and ideology differentials with an index of development. 


\section{Legislators' Value-Added: $g_{i}$}

With important exceptions, most deputies have a positive impact on $f(G)$ for most parties. In the Chamber of Deputies, size matters: most resources are allocated proportionally: committee assignments and chairships, as well as Chamber leadership positions are a direct function of party size. In addition, for members of the governing coalition, commanding additional votes usually translates into additional cabinet positions and government jobs when negotiating with the executive branch. The important exceptions include the several Brazilian parties that rely more on their ideological cohesion and policy label to generate votes than their capacity to generate pork. For such parties, ideologically-inconsistent legislators have a negative $g_{i}$ and should be denied admission.

\section{Summary of Predictions}

The preceeding discussion offers the following hypotheses regarding party membership in Brazil:

- $\mathrm{H}_{1}$ : Increasing transaction costs decreases switching.

Legislators with more partisan voters will be less likely to switch party.

- $\mathrm{H}_{2}$ : Increasing resource differentials increases switching into resource-rich parties.

State resources: Legislators stay in, or switch into governing parties, but the attractiveness of such parties may decline as coalition size grows.

Electoral Opportunity: Legislators stay in, or switch into parties with easy electoral thresholds.

Ideology: Legislators stay in, or switch into ideologically compatible parties.

Pork or Policy: Legislators from less developed regions are most responsive to resource access; legislators from developed regions are more resposive to ideological concerns.

- $\mathrm{H}_{3}$ : Parties exclude legislators with negative value-added.

Switchers will be welcomed when their value-added is positive but excluded when ideologically too inconsistent with a party. 


\section{Methods}

The formal model can be operationalized empirically as a discrete choice problem. Legislators pick the party that maximizes their expected payoff, a function of party resources less transaction costs. In a multiparty environment, we can write this as:

$$
U_{i j t}=M A X\left(U_{i 1 t}, U_{i 2 t}, U_{i 3 t}, \ldots, U_{i m t}\right)
$$

where $u_{i j t}$ is legislator $i$ 's utility of membership in party $p$ at time $t$. When party $j$ is her current party, she stays put. When $j$ is some other party, we observe a switch. I write write legislator $i$ 's utility associated with membership in party $j$ as:

$$
u_{i j t}=\beta_{0}+\beta_{1} X_{i j t}-\beta_{2} T_{i} I_{j \neq h o m e}+\beta_{3} g_{i}+\epsilon_{i j t} .
$$

where $X_{i j t}$ is a matrix of the covariates described above, and $\beta_{1}$ is a vector of coefficients. If we assume that the $\epsilon_{i p t}$ are independent and identically distributed following an extreme-value distribution, then this becomes a standard conditional logit model, also known as McFadden's choice model. Though rarely used by political scientists, the conditional logit has been widely used by economists to explore individuals' choices between products, transportation options, and, most comparable to this project, migration patterns. ${ }^{10}$

\section{Measurement}

To test my hypotheses, I collected data on party membership, constituencies, and party characteristics for all deputies during the $49^{\text {th }}$ and $50^{\text {th }}$ legislatures. Estimating coeficients requires measuring the benefits that each legislator expects to receive from each party. The unit of analysis is the legislator-month, that is, each legislator's membership choice during each month in office. ${ }^{11}$

Dependent Variable: membership at time $t$ The dependent variable follows standard practice for choice models. ${ }^{12} Y_{i j t}$ is legislator $i$ 's choice of party during month $t$, coded "1" if the legislator chose party $j$ and "0" otherwise.

Electoral Threshold I measure electoral payoff differentials with Tdiff. I first calculated Threshold for each legislator-party combination, coded "1" if legislator $i$ would have 
been elected in party $j$, and " 0 " otherwise. Finally, I calculate the threshold differential as:

Tdiff $=$ Threshold $_{i j}-$ Threshold $_{i k}$,

where $i$ references the legislator, $j$ references the prospective party, and $k$ references the current party.

This measure captures both the electoral value of a party and the marginality of the legislator. Some legislators would have been elected in any party - so party membership does not affect their electoral prospects directly. For such deputies, Tdiff $=0$ for all parties. For weaker legislators, party strength matters - some parties reduce electoral prospects; others increase them, captured in the negative or positive values of Tdiff.

State Resources Measuring the pork and other resource benefits of party membership in Brazil can be quite difficult. Because Brazil uses multi-member district elections with high district magnitude, scholars cannot easily tie government expenditures to individual legislators. One alternative would be to use budget amendments, but amendments are frequently ignored by the executive branch and are only a small part of government expenditures. In fact, the executive branch at all levels of government has very strong control over budget development, expenditures, and other components of resource distribution(Schneider, 2001). Most real access to financial resources is gained through individual legislators' lobbying of the President and Ministers, consistent with patterns observed in other countries.

How can we measure access to government resources? Ames (2001) creatively used meetings with ministers as a proxy for pork access. As no such data is available for my time period, I use two unbiased, if crude, proxies for resources access: coalition membership.

- CabDiff= $_{\text {Cabinet }}{ }_{i j t}-$ Cabinet $_{i k t}$.

Cabinet $_{i j t}$ is coded " 1 " if party $j$ was part of the president's coalition at time $t$, and " 0 " otherwise. As above, $j$ references the prospective party and $k$ references the current party.

- $G o v D i f f=G v_{i j}-G o v_{i k}$ 
$\operatorname{Gov}_{i j}$ is is coded "1" if prospective party $j$ was in the governor's office in legislator $i$ 's home state, and "0" otherwise.

Ideology I test the impact of ideological compatibility differentials on party membership using DistDiff ${ }_{i j}$, the relative proximity of prospective party $j$ versus current party $k{ }^{13}$ Ideal points are estimated using WNOMINATE method(Poole and Rosenthal, 1997).

Pork or Policy? Which of these payoffs matters most to legislators will depend on the underlying preferences of their constituents. As a proxy for preferences, I use Education ${ }_{i}$, the percentage of legislator $i$ 's constituents with four or more years of education. I interacted this variable with CabDiff, GovDiff, and DistDiff. Education is highly correlated with other demographic indicators of development. A well-known pattern in Brazilian politics, as in many other countries, is that pork, patronage, and clientelism are more common in lessdeveloped regioned, and policy promises are likely to be the currency of politics in more developed regions. CabDiff and GovDiff should have their strongest impact in low education regions; DistDiff should have its strongest impact in high education regions.

Transaction Costs Precisely identifying the partisanship of each legislators' vote share is impossible, given the lack of detailed survey data and the high district magnitude in Brazil. We can however, measure the degree to which each party has a partisan following using list votes. Voters have two choices in Brazil - to cast votes for individual candidates, or to cast votes for the overall party list. The great majority (over 90\% in 1994) cast personal votes, but this varies substantially across party. In the center-right Liberal Front Party (PFL), only about $1 \%$ of the votes were list votes, while the Worker's Party (PT) received almost $34 \%$ list votes. I use two measures of partisanship: Municipal List Voting $\left(M_{i}\right)$ and National List Voting $\left(N_{i}\right)$. For each, I take advantage of the structure of the Brazilian ballot: voters can cast votes for individuals or for the party list.

$M_{i}$ is the percentage of legislator $i$ 's electoral base that cast party list votes. Specifically, I calculated an average of list voting in the areas where each legislator received votes, weighted by what proportion of their votes were earned there. This measures partisanship among each legislator's subconstituency within a district. $N_{i}$ is the percentage of list votes received by 
the legislator's party, based on national returns. Together, these proxy partisanship. $M_{i}$ captures characteristics of the voters in $i$ 's electoral base; $N_{i}$ controls for the size of a party's following in aggregate. Because both variables were highly skewed, I used their natural logs in all models.

Legislators' Value-Added: $g_{i}$ All legislators make a small positive contribution to all parties, but deputies that are ideologically incompatible will have a negative impact on the party's policy label. This implies that a deputy $i$ 's value-added in party $j$ is:

$$
g_{i}=c-\frac{\left|\gamma_{i}-\tau_{j}\right|}{\sigma_{j}}
$$

where $c$ is the constant value-added that all parties receive, $\gamma_{i}$ is legislator $i$ 's ideal point, and $\tau_{j}$ is party $j$ 's centroid, and $\sigma_{j}$ is the standard deviation of the ideal points of party $j$ 's members. Thus, being far from a diverse catch-all party (large $\sigma_{j}$ ) is not problematic - the second term is small and $g_{i}$ is positive. But being far from a highly cohesive and unified party $\left(\right.$ small $\left.\sigma_{j}\right)$ is problematic - $g_{i}$ is negative. Unfortunately, this cannot be estimated separately from payoffs. The first term, $c$, is a constant. The second term is too highly correlated with ideological compatibility to be estimated separately. Effectively, this means that the DistDiff term must do double duty in the model - capturing both legislators' payoffs and their value-added

Controls Building on existing work on party switching, Brazilian politics and quantitative methods, I included several additional variables as controls:

- PRN controls for the anti-PRN stigma associated with that party, as President Collor was impeached for corruption in 1992. PRN is a dummy variable coded "1" for that party from the time the scandal broke until the end of the legislature (August, 1991December, 1994), and "0" otherwise.

- Home is a dummy variable identifying legislator $i$ 's current party, effectively a constant controlling for the baseline frequency of switching. 
- $\mathrm{Com}_{i t}$ is coded "1" if legislator $i$ was on a key committee, or a committee leader, at time $t$. Com should have a negative impact on switching: committee assignments are controlled by party leaders and may be lost by switching.

- Party Leader ${ }_{i t}$ : Coded "1" if legislator $i$ was a leader or a vice leader of her party within the legislature at time $t$, and " 0 " if she was not. Party leadership provides prestige, additional staff and office resources, and influence over the legislative agenda. Deputies in leadership positions should be less likely to switch.

- Incumbent is a dummy variable coded ' 1 ' for incumbents and ' 0 ' for first-term legislators. More experienced deputies should be less likely to change party.

- I also included several time-specific variables to control for key moments and differences in the legislative cycle, and to allow the underlying hazard rate of switching to vary during the legislative session.(Beck et al., 1999)

\section{Results}

Tables 4, 5, and 6 show coefficient estimates and predicted probabilities for models of party affiliation. The results show that my affiliation model fits the Brazilian case quite well. The supposedly chaotic and anti-party behavior of legislators in actuality reflects calculated and rational career moves. In particular, the data suggest that Brazilian legislators are seeking distributive, ideological, and some electoral opportunities, but institutional resources are not highly valued. Further, party-switching patterns vary with constituency types. Characteristics of the electorate raise and lower transaction costs, and shift legislators priorities between ideology and distributive functions of parties. I discuss the specific results in the following paragraphs.

First, there is evidence that legislators use Brazilian parties as electoral vehicles. Brazil's electoral rules can make election easier in some parties than in others, and party affiliation patterns take these rules into account. The coefficient on Threshold is positive and significant: legislators choose parties where vote-pooling will facilitate re-election, and avoid parties with thresholds that are too high. Table 5 shows the substantive impact - legislators more than 
twice as likely $(p=.71)$ to choose a party with an easy electoral threshold than one where additional votes are needed for re-election $(p=.29)$.

Second, legislators value ideological compatibility when choosing between parties. Deputies don't want to join, or stay in a party that is far from their own policy preferences - the coefficient on Ideol Distance is negative and significant. The impact is substantial: deputies are about 5 times more likely to pick an ideologically proximate party than one at the opposite end of the political spectrum $(p=.86$ versus $p=.14)$. In other words, the farther a deputy is from a party, the more likely she is to switch away if she is a member, and the less likely she is to switch to that party if she is not. This finding is evidence that legislators do care about ideological consistency and compatibility.

These results would hardly be surprising in most legislatures; they are potentially controversial for Brazilianists. Brazil's largest parties have been categorized as "inchoate" and "catch-all" - why should voting coalitions matter for legislators in such parties? The importance of roll-call compatibility may reflect legislators' own desire to be ideologically consistent, pressure from party leaders, or pressure from constituents. Which is at work cannot be parsed out here, but the key point is that Brazilian legislators do value parties as voting coalitions.

Third, the analysis confirms the importance of distributive capacity for legislators' careers; the coefficient for Cabinet is positive and significant. Legislators in parties with access to federal government largess are more likely to stay put, and switchers are more likely to head for such parties. When choosing between two otherwise identical parties, legislators are about twice as likely to pick a cabinet party than an opposition party: $p_{\text {Cabinet }}=.68$ versus $p_{O p p}=.32$. This is consistent with existing work on the importance of patronage in Brazilian politics(Amorim Neto, 1998).

Governors' Party is positive and significant, and the interaction of Education and Governor is negative and significant, as predicted. In impoverished and less-developed areas, voters prioritize governismo - following the state governor in exchange for access to state resources. In such areas, legislators in a gubernatorial party are more likely to stay put, and switchers more likely to make such a party their destination. This finding shows that decentralized Brazil's state politics spill over into the national arena, affecting party affilia- 
tion decisions and coalition formation. These results echo previous research on the impact of federalism on national politics in Brazil(Mainwaring, 1999; Abrúcio, 1998; Samuels, 2003), with an important additional point.

Gubernatorial influence varies with constituency type. A deputy with a low education constituency is about 3 times more likely to pick a state governor's party over a state opposition party $(p=.79$ versus $p=.21)$. But among high education constituencies, legislators are effectively ambivalent between state opposition and governing parties: $p=.53$ versus $p=.47$, respectively. ${ }^{14}$ In impoverished and less-developed areas, where voters prioritize governismo, legislators align with the state governor in exchange for access to state resources. In more developed areas, voters' demands for localistic goods decline. This decline reduces the relative attractiveness of state-ruling parties and increases the relative importance of ideological and other factors in affiliation decisions.

The other interaction effects were not significant. The Education ${ }^{*}$ Cabinet interaction is negative, as predicted, but its effect is not significant. It may be that the benefits of membership in executive coalitions vary across governmental levels. Perhaps cabinet membership provides payoffs to legislators with all kinds of constituencies, while gubernatorial affiliations are most important in backward, clientelistic contexts. The other possibility is collinearity between Governor and Cabinet status - parties in the Cabinet also tend to be parties winning gubernatorial elections. I also predicted that the interaction of Distance and Education would be negative - reflecting an increased attention to ideological consistency as voters' preferences change. However, the interaction effect is small, has the wrong sign, and is not significantly different from zero. Two interpretations are possible. The first is that my argument about voters does not apply to voting coalitions - perhaps all legislators are equally concerned with ideological consistency, regardless of their constituents' preferences. The other interpretation is that legislators with more educated constituents have already self-selected into the parties that are ideologically most proximate.

Finally, the results emphasize the importance of voters in creating strong and stable party systems. Legislators with more partisan constituencies are much less likely to ever switch party. Table 6 reports the probability that a legislator switches party during a fouryear legislative term as a function of partisanship. In all cases, the choice set is restricted 
to two identical parties, so these probabilities can be interpreted as the impact of random, unobserved, within-party personality conflicts and struggles that cause switches. The hypothetical party list voting levels are set to $0.6 \%$ (low) and $30 \%$ (high) which is slightly narrower than the actual range of the data. Legislators in less partisan parties, with personalistic constituencies, have a .061 probability of switching during their term, even when there are no payoff differentials. At the other extreme, legislators with more partisan electoral bases are very unlikely to switch, with a predicted probability of switching of just .002 over a four-year period.

The control variables are mostly as expected. Incumbency may deter switching - its coefficient is negative - though it does not reach conventional levels of significance. Party leaders, not surprisingly, were significantly more likely to stay put than non-leaders.

The results also have important implications for parties' internal organization of the Brazilian legislature. Scholars have argued that party leaders' control of the mechanisms of the Chamber of Deputies enables them to enforce discipline and maintain party cohesion. Of all resources in the Brazilian legislature, party leaders have most direct control over committee assignments. Apparently, however, this control is nearly worthless. Good committee assignments do not deter switching - the coefficient on Com is not distinguishable from zero.

The time-specific variables did shape switching frequency. Legislators were more likely to switch party around campaign filing deadlines, and significantly more likely to stay put during campaigns. The coefficient on Organize and Deadline are positive and significant, indicating that switching is more frequent during the first part of each session when coalitions, committees, and leadership are forming, and immediately prior to new election filing deadlines.

\section{Discussion}

Frequent party switching is usually treated as a simple indicator of system weakness, but can also provide a powerful and unique window on legislative behavior, allowing us to understand the functions that parties serve for ambitious politicians. I built a model of party affiliations where legislators choose parties to maximize electoral, institutional, ideological, and distributive opportunities, less a transaction cost for switching. The model and method 
could be applied to any system, and when adapted to Brazil in particular, several findings emerge.

First, legislators in Brazil use parties for electoral, ideological, and distributive ends, but not for institutional advancement. Legislators prefer membership in parties that maximize their chances of re-election, that have more access to pork, but that are also ideologically compatible with their own goals. Ironically, legislators' affiliation choices were not affected by committee assignments - the one resource that Brazilian party leaders firmly control. At the same time, stabilizing pressure comes from an unexpected source: voters. While previous work has downplayed Brazilian voters' influence on legislators, I found that deputies with more partisan constituencies face significant defection-deterring transaction costs. Legislators with partisan constituencies were about substantially less likely to switch party than those from the least partisan regions and labels.

Further, which factor matters most varies with voters preferences. Higher education voters shift legislators' efforts toward ideological concerns; lower education constituencies have other priorities, and their representatives are more likely to emphasize access to government largess in their party affiliation strategies. Scholars have found that parties play various roles in legislative systems, creating policy labels, organizing governments, mobilizing voters, and providing campaign assistance. The results from my research show how the roles parties play for politicians are not static within a political system but can vary with electorate preferences. More simply, legislators with different kinds of constituents use parties to very different ends.

Perhaps most importantly, the results show how representation works in spite of party switching in Brazil. Party switching may be viewed as a challenge to representation when voters use party labels to cast ballots and pick policy platforms. Switching effectively destroys the meaning of party labels, raises voters' information costs, and eliminates party accountibility. Switching can be viewed as a threat to the very core of democratic representation. But ultimately, it appears that switching is not the threat it appears to be, at least in the case of Brazil. Where partisanship is high and voters rely on party labels to pick candidates, transaction costs make switching very rare. Further, when legislators do switch, they are likely to move to a party with a similar ideological position - preserving the 
policy value of a vote. Finally, patterns of affiliation change to match voters' preferences for different kinds of goods. Where voters prioritize local and particularistic goods, legislators respond by switching to the parties that will maximize their ability to deliver.

My approach should be applicable in other countries. The obvious task is to carefully identify the benefits of party membership that could affect legislators' career utility, taking into account each system's institutions, norms, and transaction costs. Other political systems may offer very different incentives for the frequency and patterns of party switching, but based on my results, electoral rules, patterns of legislative organization, and voter partisanship and preferences are likely suspects for examination. Just as important, however, is a careful consideration of the nature and scarcity of payoffs of party membership.

Am important distinction is the role that parties play in controlling membership and distributing goods. In the case of Brazil, the primary payoffs to membership are either club goods, or private goods that parties do not control. But where parties do exercise control over resources, scholars will need to account for the interaction between parties and legislators.

These distinctions have important implications for the fluidity of the market for party membership. When party resources are scarce and controlled by parties, switchers need to prenegotiate access to them. For example, the US House of Representatives' "winnertake-all" distribution of committee chairships makes those positions scarce private goods. Consequently, representatives have to prenegotiate their seniority before switching, as did Billy Tauzin $(\mathrm{D} \rightarrow \mathrm{R} / \mathrm{LA})$ before he changed to the Republican Party in 1995, and Ralph Hall $(\mathrm{D} \rightarrow \mathrm{R} / \mathrm{TX})$ in 2004 . Hall retained his seniority and committee assignments, and Tauzin actually became the Commerce Committee Chair after Thomas Bliley (R/VA) stepped down.

In addition, incorporating strategic party behavior also implies broadening our focus from legislators' staying put or switching party, to also including party expulsions as part of legislators' and parties' utility-maximizing behavior. Expulsions, like party-switches, are relatively rare but not unknown. Legislators have been expelled from for corruption and inappropriate use of party resources (Mexico and India), failure to close ranks and endorse party candidates and positions (UK), not being a "real communist" (Ukraine), helping party dissidents (Ethiopia), and supporting an unpopular policy (conscription, Australia); there are many other examples. ${ }^{15}$ Including expulsions will provide a more complete picture of the 
market for parties and legislators, and also enrich our understanding of parties' collective preferences. ${ }^{16}$

Future work will face two methodological challenges. First, incorporating parties as strategic gate-keepers, and adding expulsion to their arsenal will require more complex methods than those used in previous work and in this paper. Specifically, empirical work in such systems should explicitly model the decision to accept or reject new members as a first-level selection decision that determines the choice set available to legislators at their decision stage. Second, in other cases there may be less information available about the payoffs for switching. If a legislator chooses party 1 over party 2 , we know that $U_{i 1}>U_{i 2}$. But while we may observe legislator $i$ 's subsequent benefits of membership in party 1 (renomination, a good list position, ideological compatibility), in some cases we do not have much information about legislator $i$ 's expected list position or renomination status in a party not chosen. Again, in the case of Brazil, the primary benefits of membership are easy to estimate, even for parties not chosen. But in some cases, negotiations on switches that did not happen may be private information. A Bayesian approach, treating the unobserved components of membership benefit as missing data, or a selection model would solve this information problem.

Regardless, this paper shows how party-switching provides a valuable window on the nature and functioning of party systems. Switching is frequently treated as simply an indicator of system weakness or failure. In this paper I've shown that switching is a systematic phenomenon, best understood as the rational behavior of career-seeking politicians in the absence of stabilizing transaction costs. In Brazil, switching has led scholars to describe that country as dominated by "parties for rent". My results show that while parties may be for rent, the market for membership is highly structured, rational, and constrained by both voters and institutions. The approach I advocate is easily generalizable and could yield insights for many other systems. 


\section{A Additional Information on Variables}

This appendix provides additional information on the coding of variables.

The dependent variable is party membership choice of legislator $i$ in month $t$. In a very few cases, legislators switched out of one party but remained without party membership. If they quickly moved to a new party, I ignored their time in no-party's land. Only a handful of deputies failed to ever join a new party, so I excluded them from the analysis.

If legislators changed party more than once during a month, I only counted the first switch. Again, almost no deputies made more than one switch per month. Also, a legislator in theory could start a new party or join a party with no representation, but practically all deputies moved into an existing party.

There were several party mergers and splits between 1991 and 1998. During the 49th legislature, the PCB became the PPS, the PDC and PDS became the PPR, and the PST and PTR merged to become the PTR. In the second period, the PPR, PRP, and PP merged to form the PPB, and the PCB changed its name to the PPS. I did not count any of these as party switches. For example, if a deputy from the PDS transferred to the PPR with the rest of her colleagues, I coded this as a "stay-put."

I measured constituents' education level using data from the 1990 Brazilian Census, specifically, the percentage of adults with more than four years of education. Legislators' constituents' education levels were calculated by taking the average education level from each municipality where the legislator received votes, weighted by the percentage of her votes received there:

$$
\operatorname{AvgEd}_{i}=\sum_{m=1}^{n} \text { MuniEd }_{m} * \text { Votes }_{i m}
$$

Education data came from the 1990 Census. To account for the creation of some 500 new municipalities in 1993, I re-aggregated vote shares from the 1994 election back to the 1990 municipal boundaries, then used these aggregated vote shares to calculate voter education levels.

I used a similar approach to calculating $T_{1}$, a measure of the partisanship of legislators constituents. I calculated the percent party list voting in each municipality, then calculated 
an average of these municipal-level partisanship measures, weighting by the percentage of each legislator's votes received there:

$$
M_{i}=\sum_{m=1}^{n} \text { MuniList }_{m} * \text { Votes }_{i m}
$$

Legislators' ideal points were measured using the Poole-Rosenthal NOMINATE method.(Poole and Rosenthal, 1997) Roll-call votes came directly from the Brazilian Chamber of Deputies' Secretária Geral da Mesa. The unit of analysis in each case was the legislator-party - i.e., when a legislator cast votes as a member of more than one party, I estimated separate ideal points for each party membership of that legislator.

I also included several time-specific variables to control for key moments and differences in the legislative cycle. $50^{\text {th }} \mathrm{Leg}$ is a dummy variable coded ' 1 ' for the 50 th legislature and ' 0 ' for the 49th, capturing any change in the overall switching rate and stabilization in the party system. Campaign is a dummy variable coded "1" for municipal and national campaign months. Party-switching is less likely during campaigns due to party membership restrictions for candidates and the virtual shut-down of the legislature during campaigns. Deadline is a dummy variables coded "1" for the last month when candidates can change their party before registering to run for municipal or national office. Finally, Organize is a dummy variable for the organizational period at the beginning of each legislative session, prior to committee formation and the election of Chamber leadership. This dummy variable controls for the increased switching during that period as coalitions jockey to maximize their leverage in committee assignments and leadership votes. ${ }^{17}$ Finally, I included a natural cubic spline to allow the hazard rate for switching to vary during the legislative session.(Beck et al., 1999)

For Table 5, I simulated predicted probabilities for a hypothetical legislator choosing between two parties with all variables held constant across parties, except the factor of interest. I report median simulated values and the .025 and .975 quantiles for the confidence intervals. For discrete variables, I calculated predicted probabilities for values as labeled in the table: For Governor, Gov=1, Opp=0. For Threshold, Below=0, Above=1. For Cabinet, Opposition=0, Cabinet $=1$. For the continuous variables, I used maximum and minimum values from the sample. Ideological distance was set to 1.4 (Far) and to -1.2 
(Close). Finally, Education was set to the maximum and minimum values observed in the dataset. Low Education was $14 \%$ of adults with four or more years of schooling; High education was $82 \%$ of adults with four or more years of schooling. I simulated confidence intervals by sampling from estimates' asymptotic distributions.

\section{References}

Abrúcio, F. (1998). Os Barões da Federação: Os Governadores e a Redemocratização Brasileira. São Paulo: Editora Hucitec.

Aldrich, J. H. (1995). Why Parties? The Origin and Transformation of Political Parties in America. Chicago: The University of Chicago Press.

Aldrich, J. H. and W. T. Bianco (1992). A Game-Theoretic Model of Party Affiliation of Candidates and Office Holders. Mathematical Computer Modeling, 103-116.

Ames, B. (1995a, May). Electoral Rules, Constituency Pressures, and Pork Barrel: Bases of Voting in the Brazilian Congress. Journal of Politics 57(2), 324-343.

Ames, B. (1995b). Electoral Strategy under Open-List Proportional Representation. American Journal of Political Science, 406-33.

Ames, B. (2001). The Deadlock of Democracy in Brazil. Ann Arbor: The University of Michigan Press.

Amorim Neto, O. (1998). Of Presidents, Parties, and Ministers: Cabinet Formation and Legislative Decision-Making Under Separation of Powers. Ph. D. thesis, University of California, San Diego.

Beck, N. L., J. Katz, and R. Tucker (1999). Taking Time Seriously: Time-Series-CrossSection Analysis with a Binary Dependent Variable. AJPS 42, 1260-1288.

Ben-Akiva, M. and S. R. Lerman (1985). Discrete Choice Analysis: Theory and Application to Travel Demand. Cambridge: The MIT Press. 
Bowler, S., D. M. Farrell, and R. S. Katz (1999). Party Discipline and Parliamentary Government. Columbus: Ohio State University Press.

Câmara dos Deputados (1994). Regimento Interno da Câmara dos Deputados. Brasília: Centro de Documentação e Informação.

Carey, J. M. and M. S. Shugart (1995). Incentives to Cultivate a Personal Vote: A Rank Ordering of Electoral Formulas. Electoral Studies 14, 417-39.

Cox, G. W. and M. D. McCubbins (1993). Legislative Leviathan. Berkeley: University of California Press.

Cox, G. W. and F. M. Rosenbluth (1995). Anatomy of a Split: the Liberal Democrats of Japan. . Electoral Studies 14, 355-376.

Glasgow, G. (2001). Mixed Logit Models for Multiparty Elections. Political Analysis.

Graham, R. (1990). Patronage and Politics in Nineteenth-Century Brazil. Stanford: Stanford University Press.

Grose, C. R. (2004). Is It Better to Join the Majority? The Electoral Effects of Party Switching by Southern State Legislators, 1972-2000. American Review of Politics 25, 79-98.

Haggard, S. and R. R. Kaufman (1995). The Political Economy of Democratic Transitions. Princeton: Princeton University Press.

Johnson, G. and B. Crisp (2003). Mandates, Powers, and Policies. American Journal of Political Science $47(1)$.

Keck, M. (1995). The Workers' Party and Democratization in Brazil. New Haven: Yale University Press.

Leal, V. N. (1977). Coronelismo: The Municipality and Representative Government in Brazil. New York: Cambridge University Press. 
Long, J. S. (1997). Regression Models for Categorical and Limited Dependent Variables. Number 7 in Advanced Quantititative Techniques in the Social Sciences Series. Thousand Oaks: Sage Publications.

Long, J. S. and J. Freese (2001). Regression Models for Categorical Dependent Variables Using Stata. College Station: Stata Press.

Maddala, G. S. (1983). Limited-Dependent and Qualitative Variables in Econometrics. Cambridge: Cambridge University Press.

Mainwaring, S. (1997). Mutipartism, Robust Federalism, and Presidentialism in Brazil. In S. Mainwaring and M. S. Shugart (Eds.), Presidentialism and Democracy in Latin America, pp. 55-109. New York: Cambridge University Press.

Mainwaring, S. and A. P. Liñán (1997). Party Discipline in the Brazilian Constitutional Congress. Legislative Studies Quarterly 12(4), 453-483.

Mainwaring, S. P. (1999). Rethinking Party Systems in the Third Wave of Democratization: The Case of Brazil. Stanford: Stanford University Press.

McFadden, D. (1973). Conditional Logit Analysis of Qualitative Choice Behavior. In P. Zarembka (Ed.), Frontiers in Econometrics. New York: Academic.

McLaughlin, K. J. (1991). A Theory of Quits and Layoffs with Efficient Turnover. The Journal of Political Economy 99(1), 1-29.

Mejia, A. (1999, Enero). Indisiplina y deslealtad en el Congresso. Íconos (6), 13-21.

Melo, C. R. F. d. (2000). Partidos e Migração Partidária na Câmara dos Deputados. Da$\operatorname{dos} 43(2)$.

Mershon, C. and W. B. Heller (2004a). Party Fluidity and Legislators' Vote Choices: The Italian Chamber of Deputies, 1996-2000. Working Paper.

Mershon, C. and W. B. Heller (2004b). Theoretical and Empirical Models of Party Switching. Memo Prepared for the Dublin Meeting of the Research Work Group on Legislative Party Switching, Trinity College, 4-8 July 2004. 
National Democratic Institute (1997). Strengthening Nepal's Multiparty Democracy: Party Discipline and Anti-Defection Measures. A National Democratic Institute for International Affairs Workshop.

Neto, O. A. (2002). Parties and Cabinets Dataset.

Nicolau, J. M. (1996). A migração partidária na Câmara dos Deputados (1991-1996). MONITOR PÚBLICO, 41-5.

Pereira, C. and B. Mueller (2004). The Cost of Governing: Strategic Behavior of the President and Legislators in Brazil's Budgetary Process. Comparative Political Studies 20(10), $1-32$.

Poole, K. T. and H. Rosenthal (1997). Congress: A Political-Economic History of Roll Call Voting. New York: Oxford University Press.

Reed, S. R. and E. Scheiner (2002). Electoral Incentives and Policy Preferences: Mixed Motives Behind Party Defections in Japan. British Journal of Political Science.

Samuels, D. J. (2003). Ambition, Federalism, and Legislative Politics in Brazil. New York: Cambridge University Press.

Samuels, D. J. (2004). . n.d..

Sartori, G. (1993). Nem Presidêncialismo, Nem Parlamentarismo. Novos Estudos Cebrap (No. 35), 3-14.

Schmitt, R. (1999). Migração partidária e reeleição na Câmara dos Deputados. Novos Estudos Cebrap (54).

Schneider, A. (2001). Federalism against Markets: Local Struggles for Power and National Fiscal Adjustment in Brazil. Ph. D. thesis, University of California, Berkeley.

Snyder Jr., J. M. and M. M. Ting (2001). An Informational Rationale for Political Parties. American Journal of Political Science. 


\section{Notes}

${ }^{1}$ See Carey and Shugart (1995); Bowler et al. (1999); Ames (2001), and National Democratic Institute (1997).

${ }^{2}$ Club goods may not be entirely nonrival, however: each additional member may slightly degrade the quality of the club good. For example, as a party's size grows, it may become a catch-all party, and its ideological label may lose meaning. New members with very similar ideological positions will have minimal degrading effects; legislators with distinctly different or even contradictory positions may reduce the value of the party label dramatically.

${ }^{3}$ More recently, party leaders in Ecuador agreed to allow illegal party switching to continue so a minority President could increase his legislative coalition size. The rule in Japan applies to legislators elected through proportional representation, and only prohibits switching to a party that competed in their same district.

${ }^{4}$ The market for party membership has clear parallels with labor markets, with three important differences. First, endogenous parties, not firms, make personnel decisions. Second, personnel decisions are made to maximize members' utility - not profits. Third, instead of wages, legislators receive payoffs that may be private or club goods. At this point, the model begins to bear a striking resemblance to the market for political science faculty - personnel decisions are made by majority vote to maximize departmental quality and payoffs are partly private goods (wages) and partly club goods (reputation).

${ }^{5}$ Halfway through the current legislative period there have been 135 valid switches, for a projected rate of .57 by January of 2006 .

${ }^{6}$ Candidates for office must stay in a single party in the months leading up to the election.

${ }^{7}$ This provision was recently eliminated by a court decision but was in effect for the period covered by my dataset.

${ }^{8}$ For the executive, supermajorities may well be cheaper - allowing the president to pay lower costs on a vote-by-vote basis to buy a majority.

${ }^{9}$ Under OLPR rules, Citizens cast a single vote, usually for an individual candidate. Seats are distributed to parties based on the total of votes received by all of the parties' candidates. Mandates are distributed to candidates based on the total number of votes each receives. See Ames (2001, 1995a,b), and Mainwaring (1999) for more details on OLPR.

${ }^{10}$ See McFadden (1973), Maddala (1983), and Long (1997). Alternative choice models can be implemented with more flexible error distribution assumptions, but are only tractable for smaller choice sets and datasets. See Glasgow (2001) for more details.

An alternative, and possibly more accurate, specification would incorporate parties' valuation of legislators separate from deputies' choices - a model where parties first decide whether or not to accept a legislator, then legislators choose from the choice set available to them. I have a working paper demonstrating how to estimate such a model, but it proved intractable for this dataset. 
${ }^{11}$ Why is it necessary to use a time-based measure of affiliation decisions? First, many of the key variables in the model - cabinet formation, committee assignments and leadership, party leadership, and even the party of the President, vary over time, as do many of the control variables. During one period, legislator $i$ 's party might have cabinet access. A month later, after a cabinet reshuffle, legislator $i$ might be in the opposition. Second, the actual membership of the Chamber of Deputies is constantly in flux as legislators leave and substitutes take their places. Using the legislator-month as the unit of analysis accounts for the varying amount of time that each legislator actually served in the Chamber.

${ }^{12}$ See Maddala (1983), Glasgow (2001), Long (1997), and Ben-Akiva and Lerman (1985).

${ }^{13}$ Specifically, Distance ${ }_{i p}$ is calculated as DistDif $f_{i j}=\left|\gamma_{i}-\tau_{j}\right|-\left|\gamma_{i}-\tau_{k}\right|$, where $\gamma_{i}$ is legislator $i$ 's ideal point, $\tau_{j}$ is the centroid of prospective party $j$, and $\tau_{k}$ is the centroid of current party $k$.

${ }^{14}$ All discussions of interaction effects' significance account for the covariance between the base and interactive terms.

${ }^{15}$ Indeed, there have even been a handful of recent expulsions in Brazil, nearly all from the ideological leftist parties. There were too few during the period I studied to incorporate them into this paper.

${ }^{16}$ Labor economists have argued that there is effectively no difference between voluntarily quitting a job and being fired or laid off.(McLaughlin, 1991) Firms would be happy to continue employing laid-off workers - if said workers would accept drastic pay cuts.

${ }^{17}$ Note that all variables in this model are of two possible types. Some variables simultaneously affect the decision to switch and the choice of new party; other variables only affect the decision to switch or not. A key distinction between the two is whether the variable is a characteristics of the party or the legislator. Characteristics of parties affect both decisions to switch, and destination choices. These variables include Cabinet membership, size, Threshold, Ideology, and Major Party. Coefficients on such variables indicate how the likelihood of joining a party would change if our explanatory variable were increased in value.

Characteristics of individual legislators do not, in and of themselves, tell us much about where deputies might go. For example, freshman should be more likely to switch than incumbents - but this alone does not tell us where they might go. Similarly, knowing if a legislator is a party leader or not helps us predict whether they will switch - but tells us nothing about their likely destination.

This is a natural feature of the conditional logit, more fully discussed in Long (1997). In fact, in such models, individual's characteristics cannot be included directly, but only interacted with choice characteristics. For this application, legislators' characteristics in the model were interacted with Home. A positive coefficient indicates a greater likelihood of staying in one's current party; a negative coefficient suggests the opposite. Education, as discussed, was also interacted with Cabinet, Governor, and Distance to test additional specific hypotheses. 
Table 1: Typologies of Legislative Party Systems

\begin{tabular}{|r|cc|}
\hline & \multicolumn{2}{|c|}{ Payoff Type } \\
& Club & Private \\
\hline Party Control? & I & II \\
No & I & \\
Yes & III & IV \\
\hline \hline
\end{tabular}


Table 2: Payoffs of Party Membership

\begin{tabular}{|r|cc|}
\hline & Party A & Legislator 2 \\
& & Party B \\
\hline Legislator 1 & & $\theta_{A}+f\left(g_{1}\right), \theta_{B}+f\left(g_{2}\right)$ \\
Party A & $\alpha_{1 A} \theta_{A}+f\left(g_{1}, g_{2}\right), \alpha_{2 A} \theta_{A}+f\left(g_{1}, g_{2}\right)-T$ & \\
Party B & $\theta_{B}-T+f\left(g_{1}\right), \theta_{A}-T+f\left(g_{2}\right)$ & $\alpha_{1 B} \theta_{B}+f\left(g_{1}, g_{2}\right)-T, \alpha_{2 B} \theta_{B}+f\left(g_{1}, g_{2}\right)$ \\
\hline \hline
\end{tabular}


Table 3: Party Switching Rates in the Chamber of Deputies

\begin{tabular}{|l|cccc|}
\hline & \multicolumn{5}{|c|}{ Legislative Session } \\
& 49 th & 50 th & 51 st & 52 nd \\
\hline Number of Switches & 262 & 212 & 262 & 135 \\
Switching Rate & .52 & .41 & .51 & $.54^{*}$ \\
Number of Switchers & 198 & 169 & 183 & 130 \\
\hline \multicolumn{5}{|c|}{ *current term, projected rate } \\
\hline
\end{tabular}


Table 4: Conditional Logit Model of Affiliation Decisions

\begin{tabular}{|c|c|c|c|c|c|c|}
\hline & Moc & el 1 & & Moc & el 2 & \\
\hline & Coef. & $\mathrm{SE}$ & & Coef. & $\mathrm{SE}$ & \\
\hline Payoffs & & & & & & \\
\hline Threshold & .88 & .32 & $* *$ & .89 & .32 & $* *$ \\
\hline Cabinet & 1.14 & .28 & $* *$ & .73 & .09 & $* *$ \\
\hline Cabinet*Educ. & -.80 & .53 & & & & \\
\hline Governor & 1.51 & .35 & $* *$ & 1.62 & .34 & $* *$ \\
\hline Gov. *Educ & -1.86 & .69 & $* *$ & -2.09 & .67 & $* *$ \\
\hline Ideol Distance & -.79 & .37 & * & -.71 & .13 & $* *$ \\
\hline Ideol Dist. *Educ & .15 & .64 & & & & \\
\hline Transaction Costs & & & & & & \\
\hline District Partisanship & -.40 & .07 & $* *$ & -.40 & .07 & $* *$ \\
\hline National Partisanship & -.49 & .07 & $* *$ & -.49 & .07 & $* *$ \\
\hline Controls & & & & & & \\
\hline Committee & -.02 & .12 & & & & \\
\hline Incumbent & -.19 & -.13 & & & & \\
\hline Party Leader & -.45 & -.16 & $* *$ & -.46 & .16 & $* *$ \\
\hline National Campaign & -.89 & -.25 & $* *$ & -.88 & .25 & $* *$ \\
\hline Election Deadline & 1.88 & .19 & $* *$ & 1.89 & .19 & $* *$ \\
\hline Organize Period & .91 & .27 & $* *$ & .91 & .27 & $* *$ \\
\hline $50^{\text {th }}$ Leg. & .83 & .19 & $* *$ & .81 & .18 & $* *$ \\
\hline PRN & -1.30 & .31 & $* *$ & -1.33 & .31 & $* *$ \\
\hline Home & 12.51 & .51 & $* *$ & 12.62 & .51 & $* *$ \\
\hline $\mathrm{N}$ & 43,286 & & & 43,286 & & \\
\hline LL & -1981.47 & & & -1983.76 & & \\
\hline
\end{tabular}


Table 4: Conditional Logit Model, continued

\begin{tabular}{|l|c|c|}
\hline & Model 1 & Model 2 \\
& Coef. SE & Coef. SE \\
\hline & $* .05 * * .01$ \\
\hline
\end{tabular}

Cubic spline estimates not shown. 
Table 5: Impact of Selected Party Characteristics on Predicted Probability of Membership (95\% Confidence Intervals in Parentheses)

\begin{tabular}{|c|c|c|}
\hline \multicolumn{3}{|c|}{ Electoral Threshold } \\
& Below & Above \\
\hline & 0.29 & 0.71 \\
& $(.18, .42)$ & $(.58, .82)$ \\
& & \\
\hline
\end{tabular}

\begin{tabular}{|c|c|c|}
\hline \multicolumn{3}{|c|}{ Cabinet Membership } \\
Opposition & Cabinet \\
\hline & 0.32 & 0.68 \\
& $(.29, .37)$ & $(.63, .71)$ \\
& & \\
\hline
\end{tabular}

\begin{tabular}{|l|c|c|}
\hline & \multicolumn{2}{|c|}{ Ideological Distance } \\
& Far & Close \\
\hline & .14 & .86 \\
& $(.07-.23)$ & $(.77-.93)$ \\
& & \\
\hline
\end{tabular}

\begin{tabular}{|r|c|c|}
\hline & \multicolumn{2}{|c|}{ State Coalition } \\
Education & Opposition & Governor \\
\hline Low & 0.21 & 0.79 \\
& $(.14, .31)$ & $(.70, .86)$ \\
High & 0.53 & 0.47 \\
& $(.40, .66)$ & $(.34, .60)$ \\
& & \\
\hline
\end{tabular}


Table 6: Impact of Transaction Costs on Probability of Switching

\begin{tabular}{|r|c|c|}
\multicolumn{1}{c}{$P($ Switch $)$} \\
\hline & \multicolumn{2}{|c|}{ National } \\
& Low & High \\
\hline District & & \\
Low & 0.061 & 0.010 \\
High & 0.013 & 0.002 \\
\hline
\end{tabular}


Figure 1: Party Membership Equilibria Strategies - Public Goods without Party Control

Plot I: $T=0, G=(1,1)$

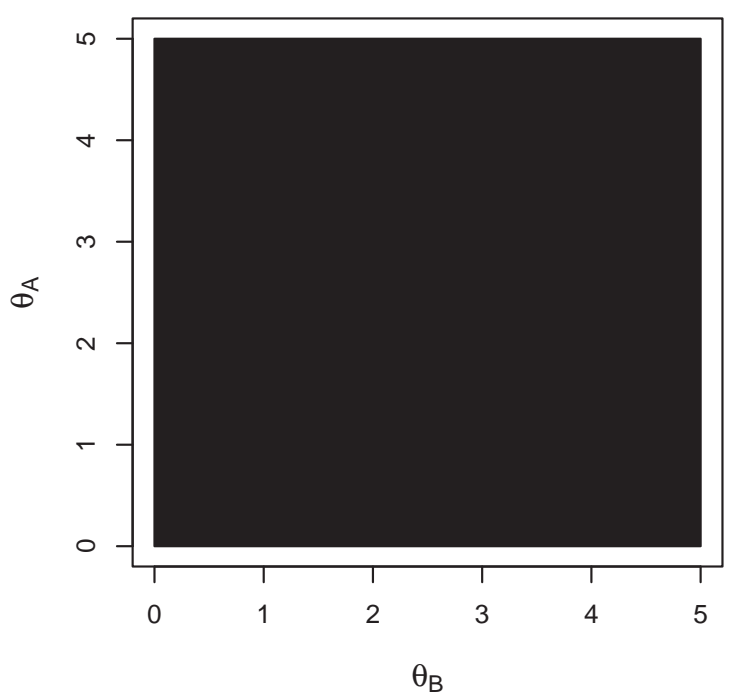

Plot II: $T=2, G=(1,1)$

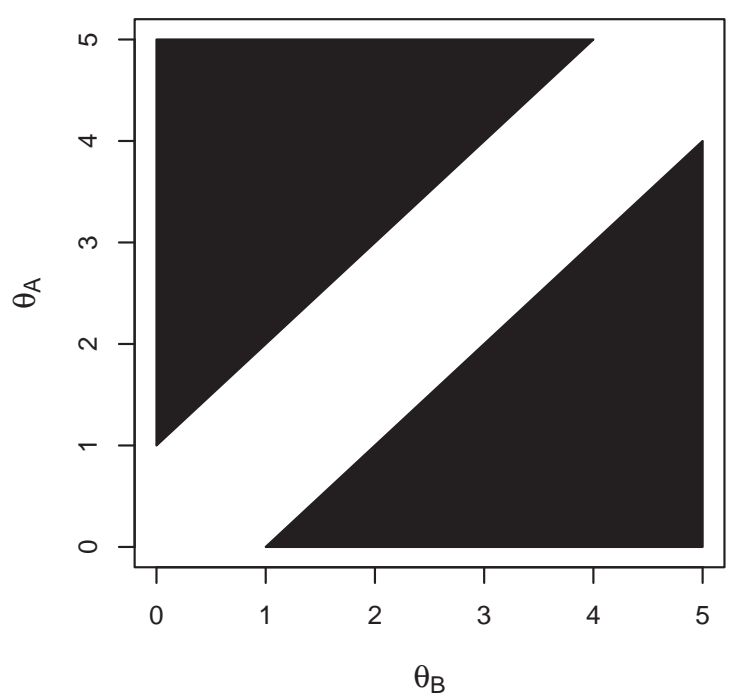

Plot III: $T=0, G=(1,-1)$

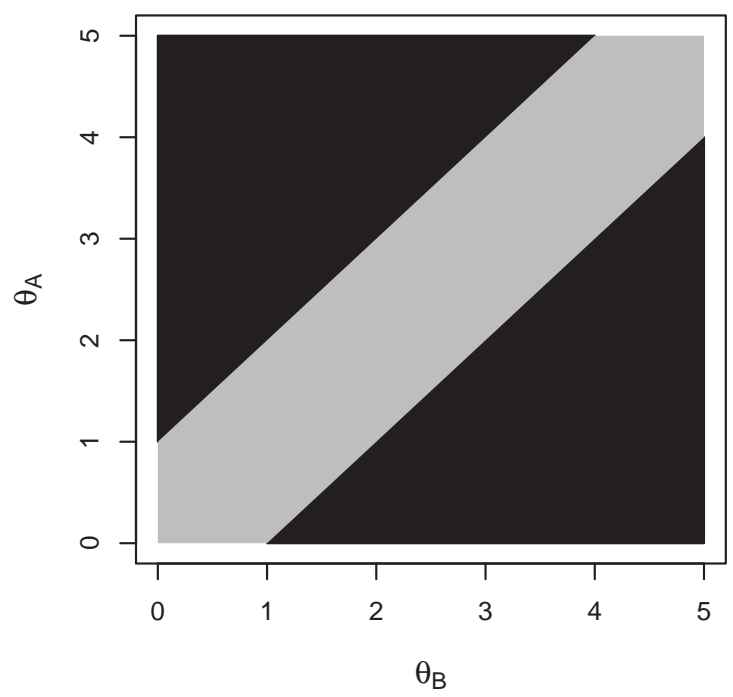

Plot IV: $T=2, G=(1,-1)$

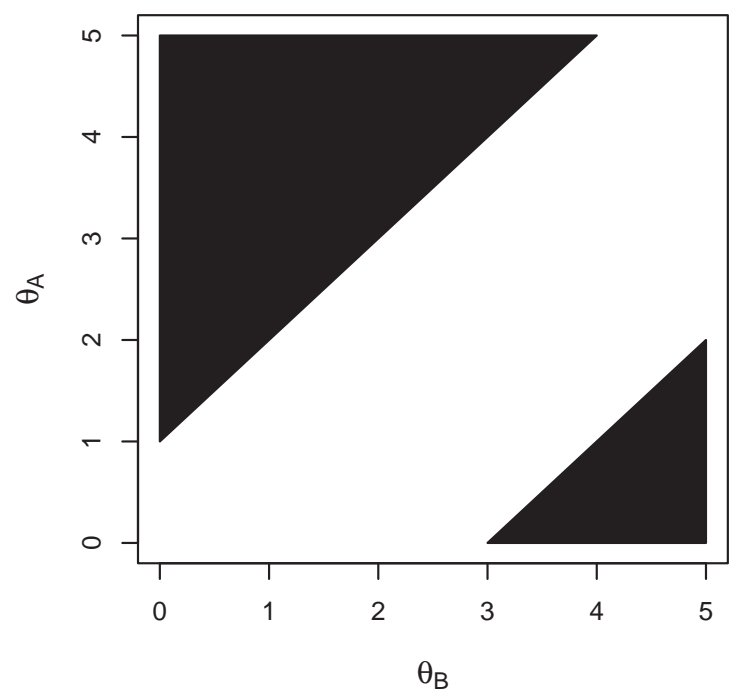


Figure 2: Party Membership Equilibria Strategies - Private Goods without Party Control

Plot I: $T=0, G=(1,1)$

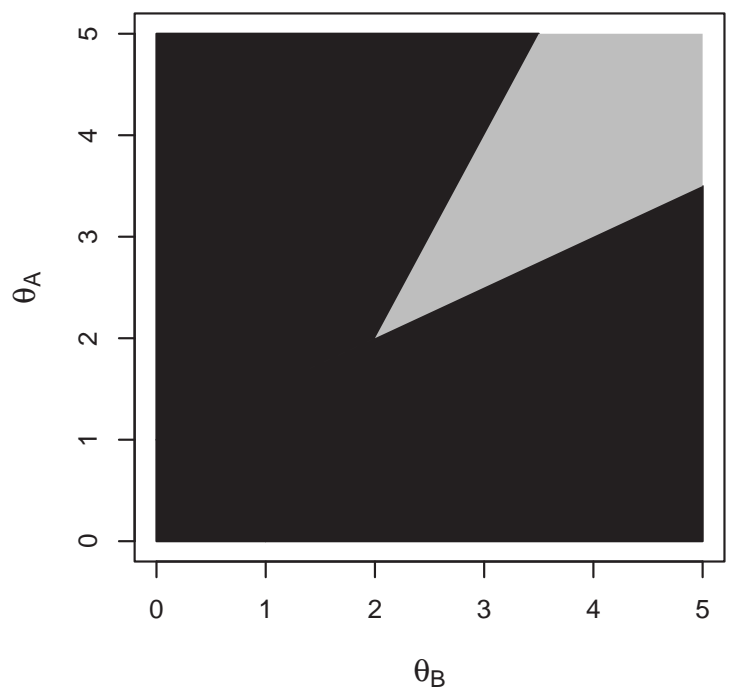

Plot II: $T=2, G=(1,1)$

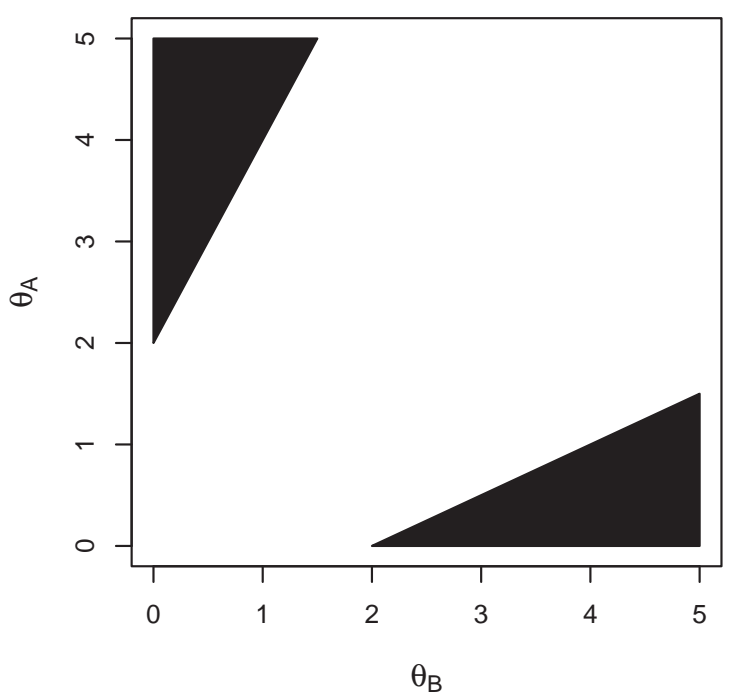

Plot III: $T=0, G=(1,-1)$

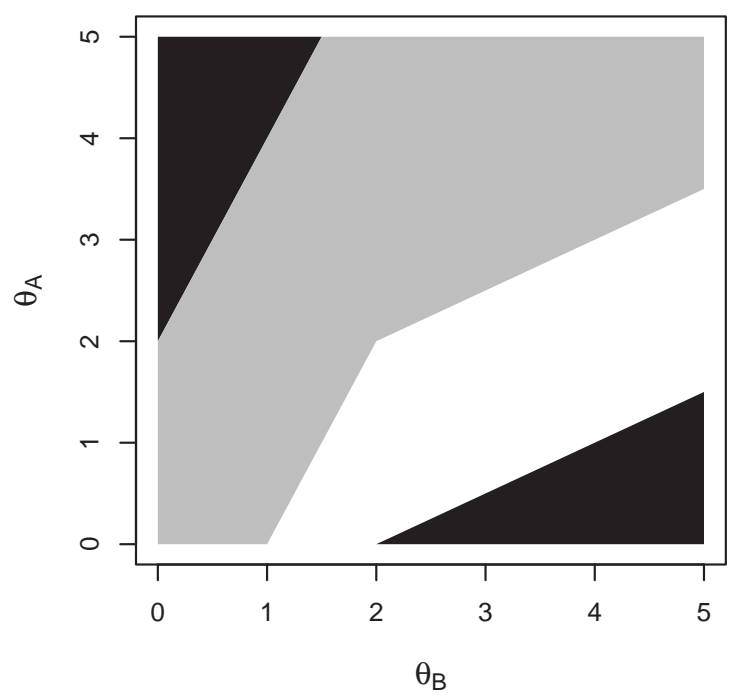

Plot IV: $T=2, G=(1,-1)$

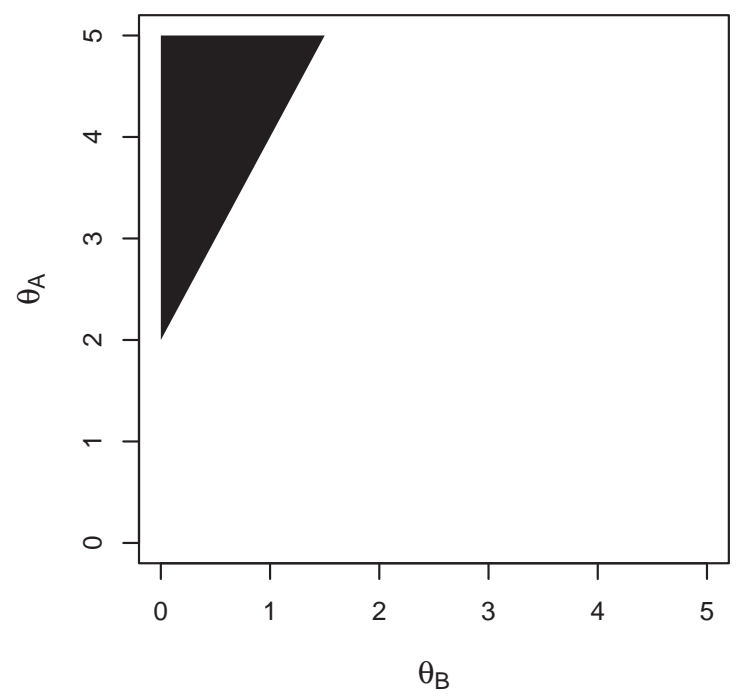


Figure 3: Party Membership Equilibria Strategies - Public Goods With Party Control

Plot I: $T=0, G=(1,1)$

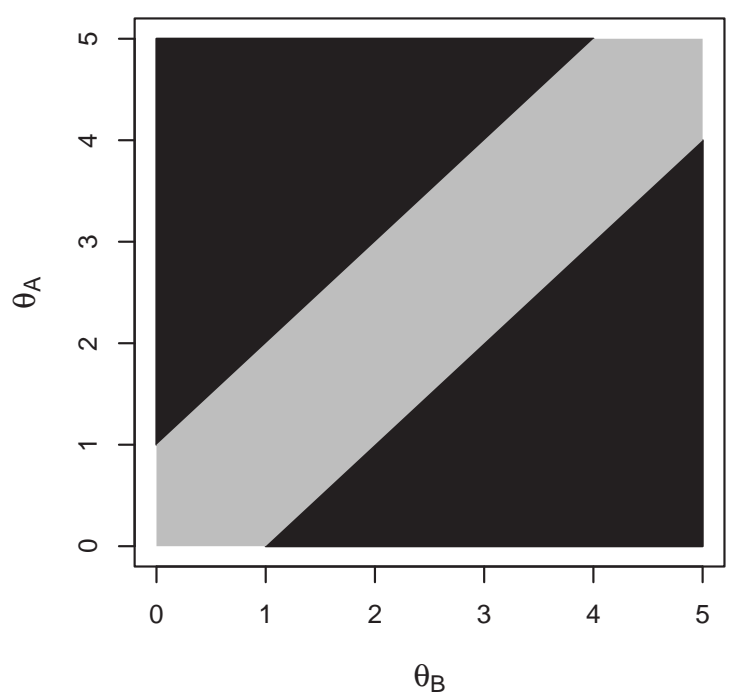

Plot II: $T=2, G=(1,1)$

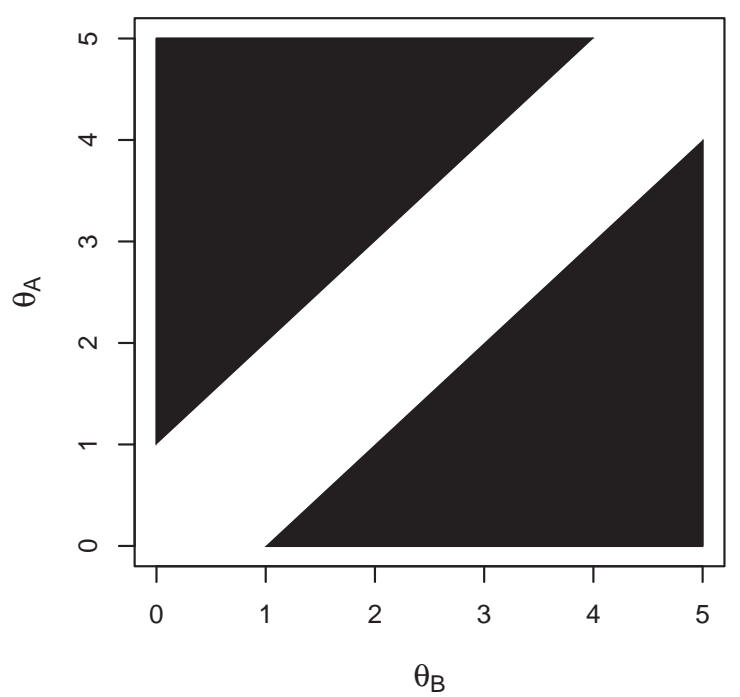

Plot III: $T=0, G=(1,-1)$

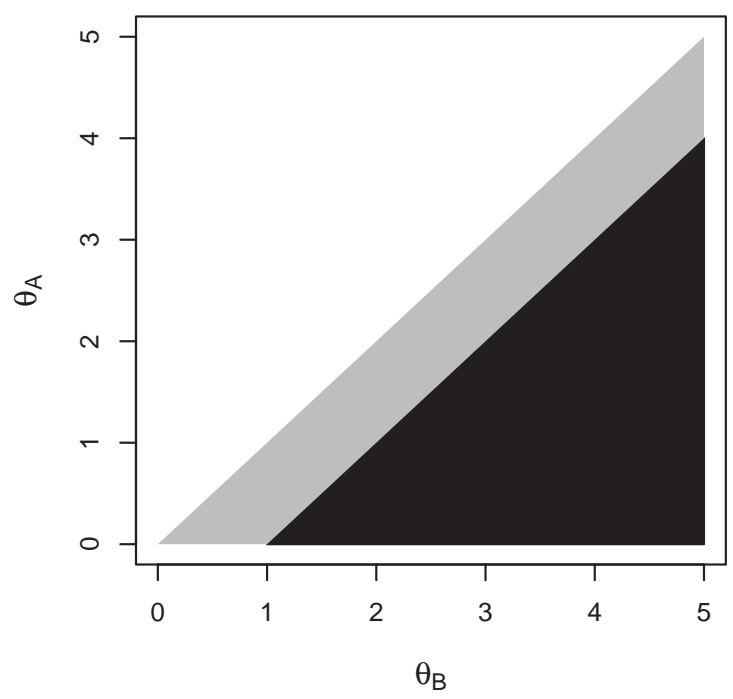

Plot IV: $\mathrm{T}=2, \mathrm{G}=(1,-1)$

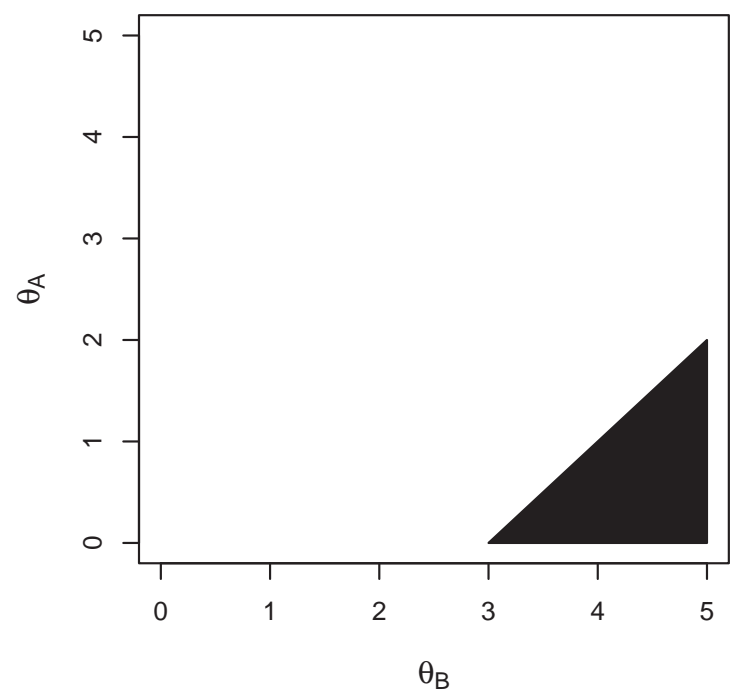


Figure 4: Party Membership Equilibria Strategies - Private Goods with Party Control

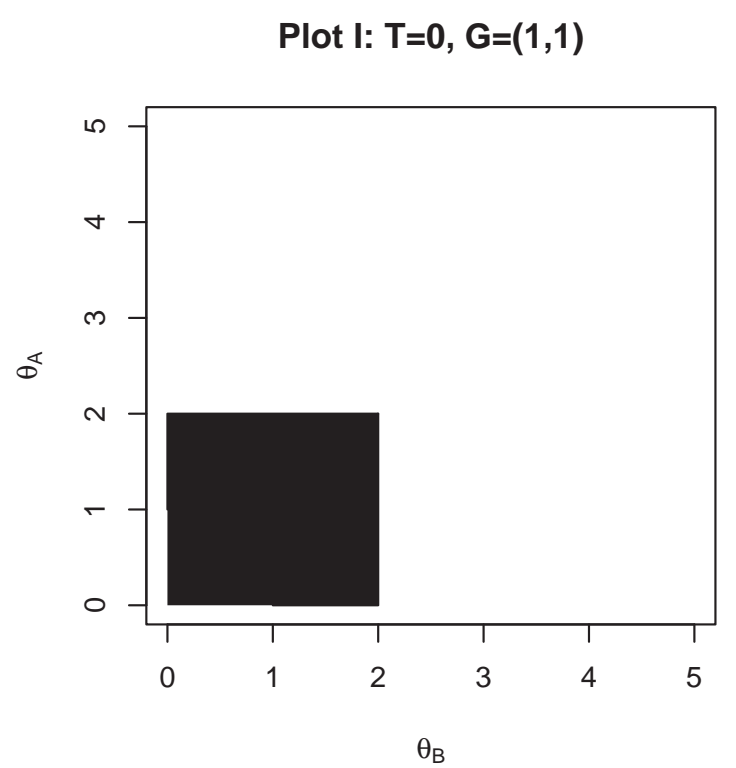

Plot II: $T=2, G=(1,1)$

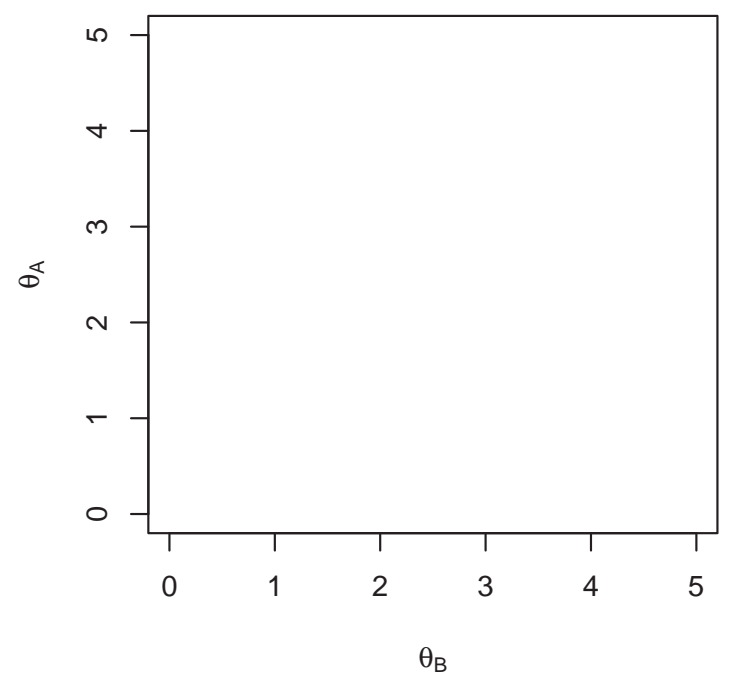

Plot III: $\mathrm{T}=0, \mathrm{G}=(\mathbf{1},-1)$

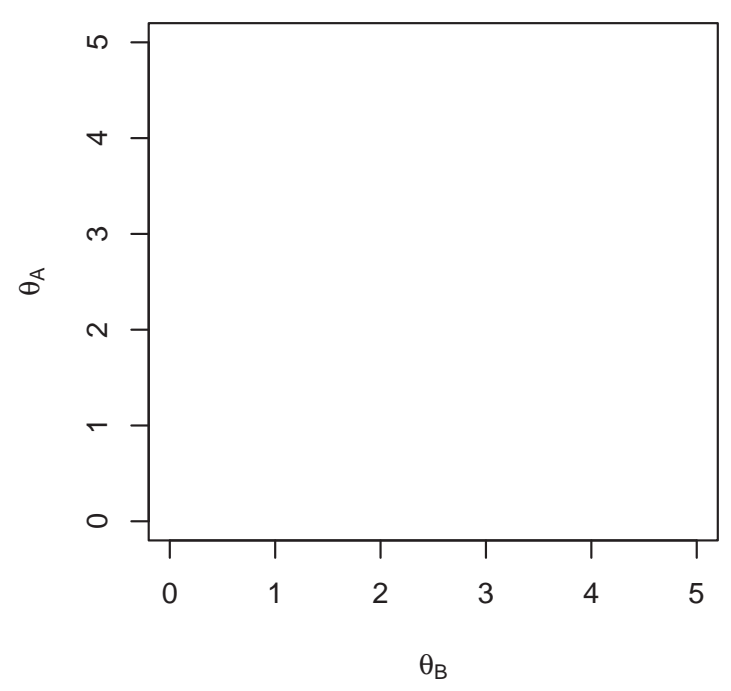

Plot IV: $T=2, G=(1,-1)$

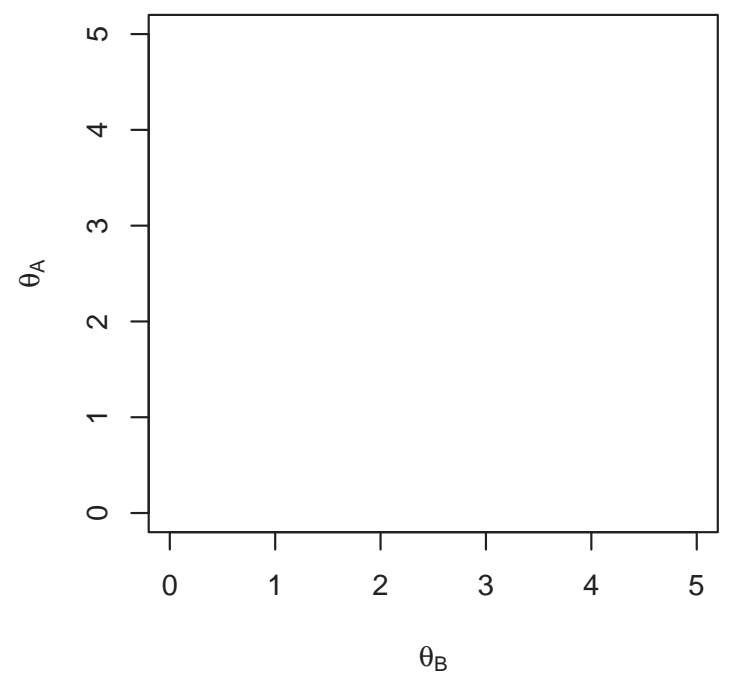

